Aletria, Belo Horizonte, v. 28, n. 1, p. 117-134, 2018

\title{
A poética da totalidade: um estudo da comicidade no drama romântico de Castro Alves
}

\section{The poetics of totality: an essay on comicality in Castro Alves' Romantic drama}

\author{
Giovanna Gobbi Alves Araújo \\ Universidade de São Paulo, São Paulo, São Paulo / Brasil \\ giovannagobbi@usp.br
}

Resumo: O presente ensaio discute a mescla de gêneros no interior da estética do drama romântico, a partir da presença da comicidade na peça Gonzaga ou a Revolução de Minas (1876) de Castro Alves. Para tal, apresento noções basilares acerca da concepção de arte dramática constituída nos escritos em prosa do autor baiano e sua filiação literária ao modelo de drama romântico proposto por Victor Hugo. Por fim, analiso os procedimentos cômicos empregados em excertos selecionados do drama em questão, considerando sua funcionalidade em relação à economia geral da obra, partindo das proposições teóricas de Vladímir Propp e Henri Bergson.

Palavras-chave: drama romântico; comicidade; Castro Alves; Gonzaga ou a Revolução de Minas.

Abstract: This article discusses the fusion of genres within the aesthetics of the Romantic drama, analyzing the presence of comicality in the play Gonzaga ou a Revolução de Minas (1876) by Castro Alves. For that, I present key notions on the concept of dramatic art forged in Alves' prose writings and his literary affiliation to the model of Romantic drama proposed by Victor Hugo. Finally, I analyze comic procedures in selected passages of Gonzaga ou a Revolução de Minas, considering their functionality in relation to the general dynamics of the play, applying the theoretical propositions of Vladímir Propp and Henri Bergson.

Keywords: Romantic drama; comicality; Castro Alves; Gonzaga ou a Revolução de Minas. 
A reputação literária de Antônio de Castro Alves (1847-1871) se firmou no século XIX, essencialmente, a partir das contribuições poéticas publicadas em periódicos acadêmicos e jornais de considerável circulação e, sobretudo, das récitas nos teatros de Salvador, Recife e São Paulo entre 1866 e $1868 . .^{1}$ Tais composições, por vezes acompanhadas de um número musical, dedicavam-se à substância lírica e à matéria política circunstancial e abolicionista, cujos debates, ainda incipientes, passavam a ganhar espaço entre o público letrado. Dessa forma, o teatro figurava na produção literária castroalvina tanto nos mecanismos técnicos de cunho dramático empregados na mobilização do pathos, quanto em seu meio social de veiculação e recepção. ${ }^{2}$ Nesse período, o predomínio do drama romântico já havia se atenuado e o repertório teatral transitava em direção à dramaturgia realista, ao mesmo tempo que vivenciava o alargamento do teatro cômico a novas modalidades. Assim, a atuação de Castro Alves no meio teatral, em associação à convivência e à parceria artística com a atriz portuguesa Eugênia Câmara, possibilitou-lhe não apenas aprofundar o conhecimento das técnicas dramáticas disponíveis, como também estar a par das tendências teatrais de seu tempo, que abrangiam desde os dramas e melodramas franceses às comédias realistas, fantasias, operetas e vaudevilles. Ainda que não tenha realizado incursões pelo gênero cômico, Castro Alves explorou aspectos da comédia tanto em sua produção poética quanto dramática. Neste ensaio, intenciono refletir sobre a atuação da comicidade na estética do drama romântico, investigando o desempenho das ocorrências cômicas na economia da peça histórica Gonzaga ou a Revolução de Minas (1876), a partir dos estudos teóricos de Henri Bergson e Vladímir Propp.

Antes de se tratar do drama castroalvino em questão, cumpre apresentar noções basilares da concepção de arte dramática do poeta baiano, extraídas de textos críticos esparsos sobre os movimentos teatrais de seu tempo, a comédia e seu papel na constituição do drama.

O teatro cômico não aparece enquanto objeto das reflexões críticas de Castro Alves, à exceção de um texto em prosa: "O eco", de 1866, no qual Castro Alves discute cinco expressões da atividade literária e tece

\footnotetext{
${ }^{1}$ Como comprovam as seções de anúncios do Diário de Pernambuco, do Correio Paulistano, do Diário de S. Paulo, d'O Ipiranga, entre outros.

${ }^{2}$ Sobre as técnicas dramáticas na poesia castroalvina, cf. ARAÚJO. A pintura das águas: um estudo da visualidade poética em A Cachoeira de Paulo Afonso de Castro Alves.
} 
considerações sobre a conjuntura teatral oitocentista. Em tom de fábula ou à moda de Les Fleurs animées (1847), de J. J. Grandville, o autor retrata um jardim antigo e encantado, no qual cada flor, ao apresentar suas particularidades por meio de um monólogo, personifica um gênero da criação literária. Lançando mão de metáforas naturais, o poeta dispõe ideias sobre a literatura, nomeia exemplos dignos de louvor e denuncia, por fim, o abandono a que estão submetidas as letras, restando ao eco das serras resgatá-las do esquecimento. À comédia, Castro Alves atribui a bonina, a "bela filha da noite", de cor vibrante e cúpula pomposa e revolta, que se queixa dos goivos, espécie que a julga por sua "vida livre e risonha". O vaudeville, "galante cavalheiro", aparece arquejante e com as vestimentas rasgadas após ser atacado por "zangões". Ambos se descrevem vítimas da condenação moral de diletantes furiosos e hipócritas, que reprovam a liberdade e a jocosidade dos gêneros cômicos. A construção metafórica dos agressores naturais ("goivos", "zangões" de "lanças envenenadas") alude aos ataques severos que a crítica teatral, mediante pareceres da censura e resenhas na imprensa, dispensava à comédia, particularmente às modalidades mais populares, como as mágicas, as operetas e o vaudeville. Àquele momento, o espetáculo alegre e ligeiro das novas formas cômicas dividia os palcos com a comédia realista realizada a partir do modelo francês de Alexandre Dumas Filho, em que os vícios da sociedade eram postos em cena para serem debatidos e corrigidos com base nos valores da ética burguesa. Assim, o teatro como instrumento de uma missão moralizadora rivalizava com o teatro como puro entretenimento, que começava a atrair a atenção de um público cada vez maior e o interesse dos empresários teatrais. ${ }^{3}$ Ao final do diálogo, a comédia zoomorfizada de "O eco", desinibida de pudores, convida suas irmãs, as flores noturnas ${ }^{4}$ - e também o público leitor - à fruição do teatro

${ }^{3} \mathrm{O}$ estudioso João Roberto Faria elenca e analisa em sua pesquisa as críticas de intelectuais, dramaturgos e artistas em relação ao teatro cômico musicado, de que são exemplos as de Francisco Otaviano, Joaquim Manuel de Macedo, Luís Leitão, Moreira de Azevedo e Xisto Bahia, afora José de Alencar e Machado de Assis (cf. FARIA. Ideias teatrais: o século XIX no Brasil, p. 160). Deixo registrado meu agradecimento ao Professor João Roberto Faria pela leitura atenta e pelas contribuições críticas para o desenvolvimento deste trabalho.

${ }^{4}$ As flores noturnas "emprestam as orelhas aos cantos do poeta". GRANDVILLE. Les fleurs animées, p. 112, tradução minha.. 
de entretenimento: "Ao cancã, viva o prazer, viva a alegria...". 5 Seja em caráter provocativo ou por gracejo, a forma imperativa e exclamativa da fala da personagem instiga o leitor-frequentador de teatro a usufruir da modalidade mais popular do teatro cômico musicado sem ressalvas. Já no interior do texto, o apelo da comédia tem o efeito de despertar suas interlocutoras-irmãs: o drama (cacto) e a tragédia (cicuta), que se apresentam, seguidamente, ao leitor. Nos momentos finais da fábula, as flores, reunidas, suplicam ao eco das montanhas que leve seus cânticos, num brado coletivo de "harmonia sublime", de modo que seu valor seja reconhecido: "- Belo eco da serra, vem ouvir os nossos murmúrios. Nós cantamos, ninguém nos ouve, nós brilhamos, ninguém nos vê, nós somos belas, ninguém nos ama". ${ }^{6}$ Ora, se a fusão entre os gênerosirmãos - comédia, tragédia e drama - é responsável por animar o hino sublime da comunhão das flores, é possível afirmar que o que subjaz essa concepção de arte é o paradigma romântico de criação literária que propõe a mistura entre opostos, mimetizando o movimento criativo da natureza. A sublimidade advinda dessa fusão remete diretamente à poética da totalidade proposta por Victor Hugo em seu Prefácio a Cromwell. Nesse manifesto sobre a estética romântica, o poeta francês preconiza que a literatura moderna misture os mais variados aspectos do real em suas criações, partindo do princípio de que "o feio existe ao lado do belo, o disforme perto do gracioso, o grotesco no reverso do sublime, o mal com o bem, a sombra com a luz." " A seu ver, o drama é a forma literária suprema, pois que "poesia completa", resulta da combinação orgânica entre o sublime e o grotesco, configurando nela mesma a "harmonia dos contrários"; ou ainda a "harmonia sublime", para utilizar a expressão de Castro Alves.

Embora a presença hugoana nas composições do poeta baiano seja vastamente reconhecida pela crítica, sua retomada se faz essencial nessa apreciação de Gonzaga ou a revolução de Minas, visto que alguns dos princípios do teatro romântico que Victor Hugo defendeu e aplicou em seus dramas, encontraram novas soluções na obra castroalvina. Corolária da visita que Castro Alves fez a José de Alencar a fim de colocar seu drama sob o escrutínio do crítico cearense, a carta deste de

\footnotetext{
${ }^{5}$ ALVES. Obra completa, p. 697.

${ }^{6}$ ALVES. Obra completa, p. 698.

${ }^{7}$ HUGO. Do grotesco e do sublime, p. 26.
} 
22 de fevereiro de 1868 a Machado de Assis sintetiza as semelhanças que Gonzaga guarda da feição literária de Victor Hugo. Para Alencar, Castro Alves segue a mesma doutrina daquele poeta francês, a do ideal, demonstrando a mesma "arquitetura do drama", o "colorido da ideia", os "toques brilhantes do estilo". Machado de Assis, em sua avaliaçãoresposta de 01 de março de 1868 , também aponta o fácil reconhecimento da "índole irmã", que aproxima o drama de Castro Alves de Victor Hugo. A seu ver, compartilham, outrossim, a inspiração e o método de composição, assentado na "pompa das figuras", na "sonoridade do vocábulo", na "forma esculpida com arte". Contudo, as similaridades não se esgotam nesses apontamentos. Afora o que indicaram os críticos oitocentistas, há na trama de Gonzaga reverberações do melodrama hugoano Hernani ou l'honneur castillan ${ }^{8}$ (1830), que foi considerado pela crítica um exemplo da nova forma proposta por Hugo em seu famoso prefácio. ${ }^{9}$ Tanto Gonzaga quanto Hernani são construídos sobre eventos de base histórica parcialmente verídica, sobre a qual se desenvolverão conflitos passionais em torno de um triângulo amoroso. Nele, a figura do herói romântico maldito, cujo nome intitula ambos os dramas, enfrenta dilemas provocados por um antagonista obsessivo que testam sua honra e lealdade. Importa a esse estudo o fato de ambas as obras adotarem os preceitos de fusão de gêneros do drama romântico - mesmo que em tonalidades variadas - cuja especificidade irei explorar adiante.

Organizado em quatro atos, Gonzaga dispõe de três fios narrativos já identificados pela crítica: ${ }^{10}$ a) o movimento revolucionário; b) a busca do ex-escravo Luís por sua filha desaparecida Carlota; c) o plano do triângulo amoroso entre Maria Doroteia, Tomás Antônio Gonzaga e o Governador Visconde de Barbacena. As onze cenas do primeiro ato chamado "Os escravos" cumprem a função de apresentar a totalidade dos personagens do drama, seus caracteres e objetivos, além de inicialmente desenrolar as três pontas da trama. As primeiras três cenas, as mais longas do segmento, dedicam-se às motivações da revolução inconfidente, à apresentação do drama do ex-escravo Luís e sua adesão à causa. As cenas IV-VIII se ocupam da complicação do enredo, dado que são introduzidos aspectos de vileza por meio da atuação de Silvério, personagem traidor

\footnotetext{
${ }^{8}$ A sugestão é de Décio de Almeida Prado em $O$ drama romântico brasileiro, p. 171. ${ }^{9}$ FREY. A Victor Hugo Encyclopedia, p. 125-126.

${ }^{10}$ PRADO. O drama romântico brasileiro, p. 176-181.
} 
vindo da "província de Satanás", que intimida os insurgentes e chantageia sua escrava Carlota a revelar informações de sua senhora Maria Doroteia. Já as cenas finais expõem rapidamente as confidências de amor entre Maria e Gonzaga e agravam a trama ao fazer com que os papéis com os planos da revolução passem das mãos de Gonzaga às de Carlota, elevando a tensão do público e retendo sua atenção para o segundo ato.

"Anjo e demônio" é o título do segundo ato, que se concentra no destino dos papéis incriminatórios dos membros da conspiração. Por uma sucessão de logros, os papéis chegam às mãos do Visconde, que utiliza de sua posse para chantagear Maria a lhe esposar. Maria, que já havia tido maus pressentimentos, usa de dissimulação para ludibriar o vilão com papéis falsos e queimar os papéis verdadeiros diante deste. $\mathrm{O}$ título do ato é assim justificado pela fala final de Maria que, com argúcia, afirma que "o anjo queimou as asas do demônio"."

O terceiro ato, "Os mártires", se desenvolve em uma noite tensa de complô, emboscada e reviravoltas, na qual os insurgentes se preparam para a fuga e os vilões, para impedi-los, por meio da infiltração de Carlota disfarçada de homem. A meio ato, ocorre o reconhecimento de Carlota por Luís graças ao rosário que carrega consigo. O par romântico, Gonzaga e Maria, consegue fugir por auxílio de Carlota, antes da chegada de Silvério e do Governador. Carlota, capturada por sua traição, suicida-se no fim do ato, que termina em nota trágica. A fala final de Luís, comovido diante da filha morta, denuncia - de forma pouco problematizadora - o sacrifício de uma classe escravizada: "que o teu sangue puro, caindo na face do futuro, lembre-lhe o nome dos primeiros mártires do Brasil". ${ }^{12}$

Transcorrido na prisão da Ilha das Cobras, o último ato, permeado de arroubos melodramáticos e certa inverossimilhança, expõe variações de atitude nos personagens masculinos principais. A princípio, o Visconde demonstra arrependimento pelos atos infames que cometeu, responsabilizando Silvério. Em seguida, coage Maria a aceitar o casamento com ele em troca da soltura de Gonzaga e dos inconfidentes. No confronto final com seu antagonista, Gonzaga desacredita do amor de Maria por encontrar prova de seu acordo com Barbacena. Finalmente, Luís afirma a inocência de Maria, revelando a chantagem do Governador, a que havia presenciado, em esconderijo. Num fim trágico, os amantes

\footnotetext{
${ }^{11}$ ALVES. Obra completa, p. 617.

${ }^{12}$ ALVES. Obra completa, p. 639.
} 
se despedem diante da inevitável execução ou degredo de Gonzaga, que parte para "agonia e glória". A peça é encerrada com uma récita cantada por Maria de um poema sobre os mártires inconfidentes.

Ao classificá-lo como "drama histórico brasileiro" - escolha marcadamente tardia em contexto brasileiro de finais de $1860^{13}$ - Castro Alves revela sua filiação primeira ao drama romântico em sua vertente histórica. Conforme aprendemos com Décio de Almeida Prado, se a faceta preponderante do drama romântico é a liberdade, ele se justifica como gênero de eleição para uma peça que objetiva debater a "essência da nacionalidade" e o direito à autonomia política de um povo. Não por acaso, a personagem do vigário Carlos Toledo, no primeiro ato, filia a Inconfidência Mineira ao paradigma histórico da Revolução Francesa, ambas favorecidas pela proteção divina. Sob a ótica castroalvina, esse pressuposto político implica no ideal de liberdade para todos, ancorado no reconhecimento da deslegitimação dos direitos dos diversos grupos sociais. Nas palavras de Gonzaga: "O escravo tem o azorrague, o trabalhador o imposto, o colono a lei, a inteligência o silêncio, o coração a morte e o povo trevas. É a Metrópole! é sempre a Metrópole. E agora, senhores, é preciso que isto acabe". ${ }^{14}$ Dessa forma, o tema do abolicionismo se alia ao da Inconfidência, conferindo, conforme observou Décio de Almeida Prado, atualidade ao drama na segunda metade do século XIX e justificando a inserção dessa discussão no seio do embate político entre a tirania da metrópole portuguesa e as demandas por soberania da colônia.

Além da adequação ao tema, a adoção do drama romântico permitiu ao autor a liberdade composicional de explorar uma abertura de forma tout-en-un e transitar entre gêneros dramáticos distintos. Nesse sentido, afirmo que Castro Alves seguiu à risca a lição dramática de Victor Hugo, que recomenda a fusão entre o trágico e o cômico no teatro, como revelara o cotejo de "O eco" com o Prefácio de Cromwell.

Dito isso, passo à análise de algumas passagens cômicas identificadas no drama, com especial ênfase nos mecanismos empregados

\footnotetext{
${ }^{13}$ Como Castro Alves, outros dramaturgos "retardatários" e afastados dos centros de produção dramática optaram pelo gênero - a saber, Agrário de Menezes e Paulo Eiró - com vistas a problematizar a questão da escravidão na sociedade brasileira (PRADO. O drama romântico brasileiro. p. 195-196).

${ }^{14}$ ALVES. Obra completa, p. 585.
} 
para garantir sua comicidade, assim como na sua funcionalidade no interior do entrecho. Ao passar as ocorrências cômicas de Gonzaga ou a Revolução de Minas em revista, torna-se saliente a concentração dos eventos de comicidade em torno de dois personagens - não por acaso, secundários: Cláudio Manuel da Costa e Joaquim Silvério dos Reis. O poeta e inconfidente Cláudio representa a maior fonte de comicidade da peça, cujos caracteres específicos, como sua inclinação pândega e galanteadora, rendem tiradas cômicas eficientes. Mesmo Machado de Assis, para quem a caracterização do conjurado Cláudio surge como evidência de fidelidade histórica na peça, acentua, na crítica do Correio Mercantil, a qualidade jocosa de sua presença:

E Cláudio, o doce poeta, não o vemos todo ali, galhofeiro e generoso, fazendo da conspiração uma festa e da liberdade uma dama, gamenho no perigo, caminhando para a morte com o riso nos lábios, como aqueles emigrados do Terror? Não lhe rola já na cabeça a ideia do suicídio, que praticou mais tarde, quando a expectativa do patíbulo lhe despertou a fibra de Catão, casando-se com a morte, já que se não podia casar com a liberdade? ${ }^{15}$

A atuação cômica de Cláudio ocorre, em geral, ao lado de Tiradentes, personagem de comportamento sério e obstinado pela resistência contra a metrópole, que lhe faz o contraponto ideal do ponto de vista cômico, servindo de apoio para seus gracejos. Em menor grau e em momentos esparsos do drama, Silvério, traidor dos inconfidentes e braço direito do Visconde de Barbacena, opera enquanto agente cômico junto ao Governador de modo a ridicularizá-lo, conforme mostrará a análise dos exemplos selecionados.

Logo na terceira cena do primeiro ato, Gonzaga apresenta Luís aos inconfidentes e lhes pede para desvendar qual seria o maior sonho do ex-escravo. Cláudio tenta algumas vezes, sem sucesso. Primeiro, vaticina que Luís deseja o amor, a que o ex-escravo responde negativamente. Depois, antevê que Luís quer riqueza; hipótese que é igualmente negada. Em seguida, Cláudio prediz que Luís anseia por mulheres, sendo, mais uma vez, refutado. Por fim, supõe que o ex-escravo almeja posição e grandeza; em vão. A cada erro de Cláudio, aumenta o suspense em relação ao acerto e a resposta contrária adquire, progressivamente,

${ }^{15}$ ALVES. Obra completa, p. 796-797. 
tonalidade cômica. Na quarta tentativa frustrada, Cláudio rebate, em tom debochado, "Ainda não? Com mil diabos, és difícil de contentar."16 O cômico situacional advém do encadeamento mecânico de sugestões e negativas, que se assemelha ao ritmo uniforme de uma mola que se contraia e se distenda, em que um ímpeto avança em um determinado sentido, para então recuar diante de uma teimosia que o suprime. ${ }^{17} \mathrm{E}$ dessa forma que o filósofo Henri Bergson explica o funcionamento usual do recurso da repetição na comédia clássica. Portanto, não se trata de uma comicidade inerente às palavras, mas daquela advinda do jogo entre intenções que se mecaniza e que a réplica final impaciente de Cláudio, ao desconstruí-lo, torna risível. No interior desse ato introdutório, a passagem tem a função de definir o temperamento da personagem para o público/leitor e, deste ponto em diante, intensificar gradualmente a expectativa cômica toda vez que Cláudio surgir em cena. Enquadra-se na mesma lógica o comentário de Cláudio, na cena seguinte, sobre a primeira aparição de Silvério num cavalo desgovernado - que o mataria, não fosse a intervenção do ex-escravo Luís. Diante da preocupação de Gonzaga, que antecipa o acontecimento de uma desgraça ao perceber o galope desabrido em que vinha o homem desconhecido, Cláudio lança a observação irônica: "Olá! que formidável salto!"18 A incompatibilidade evidente entre o evento de grave perigo e a inversão do juízo elogioso de Cláudio é causa de riso imediato e só é possível graças ao procedimento da ironia zombadora que, segundo o linguista Vladímir Propp, ao apontar positivamente para algo que é indubitavelmente negativo, realça, de forma alegórica, o defeito daquele sobre quem se tece o comentário irônico. ${ }^{19}$ Assim, o vilão Silvério é apresentado ao público/leitor com reservas, ou seja, alguém cujo caráter duvidoso o predispõe a pilhéria.

O tema da morte por enforcamento, nos segundo e terceiro atos, proporciona inteligentes efeitos humorísticos. Na cena que abre o segundo ato, os inconfidentes estão no baile de celebração ao noivado de Maria e Gonzaga a comentar sobre o risco de sofrerem pena capital pelo crime de traição à Coroa portuguesa. Tendo iniciado a discussão, Cláudio advoga que a morte pela forca é abominável. Contudo, seus argumentos

\footnotetext{
${ }^{16}$ ALVES. Obra completa, p. 587.

${ }^{17}$ BERGSON. O riso, p. 58-63.

${ }^{18}$ ALVES. Obra completa, p. 590.

${ }^{19}$ PROPP. Comicidade e riso, p. 125.
} 
contrariam a expectativa da plateia, visto que se baseiam em motivos frívolos, como a deselegância do robe de condenado. Em suas palavras:

- Ah! meus senhores, eu nunca o quereria; Deve machucar as rendas, estragar a elegância dos nossos vestidos... e, demais, é um pouco ridículo passear de robe de chambre pela rua com um pregoeiro que nos soletra horrivelmente o nome... e o carrasco imundo como o carniceiro a falar com um certo ar de proteção... Nada! nada! abomino a forca... E se temos alguma dama que nos olha nessa tão irrisória posição, ouvi-la-emos dizer talvez ao moço com quem conversa na varanda: - Sabe! quem vai ali? Um condenado. Meu Deus... como é feio um condenado... - Meus senhores... um condenado é uma espécie de rês bípede... nada! fora com a forca. ${ }^{20}$

Para a personagem, a morte por si só não é um evento rejeitável pior do que morrer é ser ridicularizado no processo, ao ter suas elegantes roupas destruídas, ao caminhar às ruas trajado de camisola, ao ter o nome erroneamente anunciado, ao ser conduzido por um carrasco arrogante, além de obter o desprezo das damas da sociedade, que o verão passar em tais condições; como se a condenação por um crime já não lhe tivesse causado vexame. Assim, defenderá a distinção do suicídio pelo punhal - "a arma das mulheres mais lindas do mundo" 21 - em detrimento da humilhação da morte pela forca: "É galhardia de cavalheiro". ${ }^{22}$

Num primeiro plano, a comicidade advém de três níveis de contraste: o primeiro, mais direto e observável, entre a nobreza de pensamento de Tiradentes sobre a morte nobre de um mártir, que antecede o comentário acima, e a frivolidade das preocupações de Cláudio; o segundo, entre a temeridade de um assunto lúgubre e a leviandade com que a personagem cômica trata a questão; e o terceiro, entre a expectativa despertada no público sobre as razões pesarosas que fariam alguém a abominar a morte e sua frustração imediata. Outrossim, o potencial da cena de arrancar o riso da plateia pode residir na observação de um traço imutável do caráter da personagem. Tida por Bergson como forma

\footnotetext{
${ }^{20}$ ALVES. Obra completa, p. 600.

${ }^{21}$ ALVES. Obra completa, p. 600.

${ }^{22}$ ALVES. Obra completa, p. 600.
} 
superior do cômico por equivaler a uma moldura essencialmente risível, ${ }^{23}$ a vaidade aproxima Cláudio de um tipo cômico, pois que o desvio fundamental de sua personalidade o enrijece, tornando-o portador de uma ideia fixa que mecaniza sua conduta: a galanteria. Por isso, defende a preservação de sua aparência a todo custo com vistas à conquista das mulheres, ainda que a morte venha a impossibilitar esse intuito. Sucedendo diretamente o ápice dramático do fim do primeiro ato, no qual Maria Doroteia desmaia diante do Governador e perde os papéis que incriminam Gonzaga, a situação cômica provocada pela vaidade excessiva de Cláudio proporciona o alívio cômico necessário ao equilíbrio da peça. Afinal, sabe-se, com Victor Hugo, que a alternância de sensações é fundamental no drama romântico, porque "tem-se necessidade de descansar de tudo, até do belo." ${ }^{24}$ Ao contrário de um lance irrefletido, a construção da passagem cômica na abertura do segundo ato demonstra consciência por parte do autor desse princípio constitutivo do drama romântico.

De modo análogo, um evento cômico gera a atenuação da tensão dramática na cena XII do segundo ato. A partir do momento em que Gonzaga pede de volta os papéis dos planos da revolução à Maria e ela não os encontra, cria-se uma desordem no enredo que mobiliza Maria e Carlota a saírem a sua procura. Isso porque o desaparecimento do dossiê implicaria na divulgação de evidências que acarretariam a prisão e execução dos inconfidentes. A situação somente se esclarecerá na cena XIV, quando o Governador revelará estar em posse dos documentos. Entretanto, antes disso, os conjurados se encontram e discutem os próximos passos rumo à revolução. Tiradentes pressiona os demais a executarem o plano sem delongas e é mal compreendido por Cláudio, que, diante da ambiguidade da fala, pensa que o amigo tratava de outro assunto:

\footnotetext{
${ }^{23}$ BERGSON. O riso, p. 121-122. Em outra passagem, Bergson reitera a comicidade do esquema prévio do tipo: "O que é cômico é a distração de si próprio, é a inserção, por assim dizer, numa moldura já preparada. E o que sobretudo é cômico é a passagem à categoria de moldura onde outros virão inserir-se, solidificar-se em caráter" (BERGSON. O riso, p. 106).

${ }^{24}$ HUGO. Do sublime e do grotesco, p. 33 .
} 
GONZAGA (aos que entram): Entrem, meus senhores, precisava falar-lhes.

TIRADENTES: E eu queria dizer-te que já não podemos esperar!

CLÁUDIO: Sim! Eu não espero mais que 24 horas. Devo morrer, meus amigos, sou o mais infeliz dos homens. Nem a brisa nem a noite, nem a música enterneceram o coração de minha Eulina. Ah! senhores, imaginem que em meio de uma declaração de amores, quando minha voz era mais terna... (e tão terna que eu mesmo quase me apaixonava pela minha garganta) quando ensaiava um beijo... mas um beijo... mas um beijo que infelizmente ficou só em hipótese, foge ligeira a minha ninfa e deixa-me chamando embalde.

Cláudio também não podia mais esperar, mas não era pela revolução; e sim, por sua amada, Eulina, que recusava reiteradamente o seu amor. ${ }^{25}$ Aqui, Castro Alves aposta no conhecido princípio cômico da confusão gerada pelo entendimento de uma informação como se fosse outra - o quiproquó. A graça suscitada pela confusão provém, primeiramente, do fato do público/leitor ter acesso a todas as facetas da situação, enquanto a personagem conhece somente parte da situação. Avançando nessa reflexão, Henri Bergson explica que o quiproquó desperta o riso porque manifesta a "interferência de séries independentes", ${ }^{26}$ isto é, cada série de eventos referente a seu personagem corre paralelamente até um momento de coincidência em que elas, convenientemente, se entrecruzam. É precisamente esse encontro que origina o efeito cômico. A comicidade é dilatada nesse segmento, ainda, pelo emprego de outra técnica cômica, baseada não na interferência de séries, mas na transposição de linguagem. Quando Cláudio discorre sobre seus esforços máximos para seduzir a amada, confessa que sua voz era tão afetuosa que por pouco ele não se arrebata de amores por sua própria garganta. Assim, passa-se do âmbito do cômico da situação para o das palavras. Transpondo a linguagem solene (da declaração de amor) à trivial

\footnotetext{
${ }^{25}$ Chama-se Eulina a amada de Cláudio Manuel da Costa enquanto personagem nos versos árcades de Tomás Antônio Gonzaga. Na parte I da lira XVI, Eulina é descrita como ingrata e dotada de uma personalidade impetuosa, inferior à de Marília; não sendo, portanto, merecedora dos afetos de Cláudio.
}

${ }^{26}$ BERGSON. O riso, p. 74. 
(sua própria garganta), a personagem produz um rebaixamento abrupto, ao mesmo tempo que excede na proporção de seu sentimento. Tanto o mecanismo de degradação quanto o do exagero são expressões, segundo Bergson, da mesma forma de comicidade. Com tais escolhas, Castro Alves parece seguir, pois, a recomendação de Gonçalves Dias no prólogo de Leonor de Mendonça, em que indica a "quebra de gravidade" realizada pela comédia como necessária para que a parcela trágica do drama se sustente. ${ }^{27}$ Deste modo, em meio ao escalonamento da complicação do enredo, o autor lança mão das técnicas cômicas apresentadas a fim de promover uma interrupção da sobrecarga dramática para, em seguida, recobrar a atenção do público para o desdobramento da ação.

A fim de explorar mais um procedimento cômico empregado em Gonzaga ou a Revolução de Minas, recupero um episódio da dupla de vilões, Silvério e o Visconde de Barbacena. No último ato, marcado por forte apelo emocional nos encontros e despedidas entre Gonzaga e Maria Doroteia, a presença cômica recua em comparação aos demais atos. Todavia, ela é preservada enquanto artifício de alternância na mescla romântica entre os gêneros dramáticos. Posicionada entre cenas notadamente confessionais de Gonzaga (cenas I e II) e do Governador (cena V), a passagem cômica das cenas intermediárias rompe o padrão melodramático da exacerbação do sofrimento por amor e introduz, ainda que brevemente, um respiro cômico que procura compensar o excesso sentimental. Mesmo após o aprisionamento de Gonzaga, o Governador não tem êxito em convencer Maria a ser sua esposa e apresenta uma mudança temporária de atitude, a partir da qual aparenta se arrepender dos atos maléficos cometidos no passado. Defeito de inverossimilhança da peça, o câmbio frouxo de intenção mobiliza artificialmente a expectativa do público em direção à possível libertação dos inconfidentes. Nesse contexto, o Governador culpabiliza Silvério e imputa a sua influência satânica a responsabilidade pela corrupção de seu caráter. Perplexo diante da inconsistência do tirano, Silvério dispara sua indignação cômica num aparte à plateia: "Comédia! comédia! comédia! Este homem será sempre um mau ator. Mistura Satanás com Cristo e não sabe ser bom, da

\footnotetext{
${ }^{27}$ FARIA. Ideias teatrais: o século XIX no Brasil, p. 350. O crítico João Roberto Faria identifica no prólogo de Leonor de Mendonça repercussões das ideias de Victor Hugo no Prefácio de Cromwell, que Gonçalves Dias parece aplicar em seu drama (cf. FARIA. Victor Hugo e o teatro romântico no Brasil, p. 113).
} 
mesma sorte que não presta para mau." ${ }^{28}$ Ao comentar sobre a atuação da personagem do Visconde enquanto "mau ator", Silvério promove a quebra da ilusão dramática com seu comentário ambíguo, que pode igualmente ser estendido à performance do ator no papel de Barbacena. Recurso cômico da farsa e do melodrama, ${ }^{29} \mathrm{o}$ aparte atua menos para esclarecer ou prevenir o público sobre o vilão do que para ridicularizá-lo. A cena seguinte (IV) corrobora o posicionamento anterior de Silvério. Quando Maria chega a pedido do Governador, ele a cumprimenta com o comentário: "Minha senhora! eu não contava com tanta pontualidade". ${ }^{30}$ Silvério, então, rebate com uma observação breve e involuntária: "Eu contava, porque ela ama aquele homem". ${ }^{31}$ A irritação do Governador com a argúcia de Silvério comprova a eficácia zombeteira de sua fala ("Tu és o demônio. Vai-te." 32 ). A cena faz rir pela inversão de papéis que o chiste de Silvério provoca. Subordinado a Barbacena, Silvério se dirige usualmente ao chefe com servilismo; seu gracejo inteligente o eleva ao mesmo tempo que rebaixa seu superior. Da sensação de "mundo às avessas", ${ }^{33}$ deriva a comicidade e o prazer do público/leitor com esse tipo de inversão de papéis proveniente da farsa. Ademais, os mecanismos de ridicularização engajados por Silvério são somados a um substrato social que evidencia sua comicidade. De acordo com Propp, o cômico e seu aspecto social são inseparáveis; portanto, a compreensão de uma área contribui ao entendimento da outra. $\mathrm{O}$ conteúdo social presente na dinâmica entre Silvério e Barbacena, ou seja, a mecânica do poder e da influência política, preenche a engrenagem cômica formatada, deixando-a ainda mais engraçada. Assim sendo, os apartes e chistes de Silvério, bem como os insultos farsescos próprios de seu rebaixamento, atuam no sentido de promover uma espécie de desmascaramento da figura de "representante oficial do poder", ${ }^{34}$ i.e., a autoridade corrupta a que está submetido. Dessa forma, o último ato de Gonzaga permite

\footnotetext{
${ }^{28}$ ALVES. Obra completa, p. 644.

${ }^{29}$ PRADO. A personagem no teatro, p. 89.

${ }^{30}$ ALVES. Obra completa, p. 646.

${ }^{31}$ ALVES. Obra completa, p. 646.

${ }^{32}$ ALVES. Obra completa, p. 646.

${ }^{33}$ BERGSON. O riso, p. 73.

${ }^{34}$ PRADO. História concisa do teatro brasileiro, p. 72.
} 
entrever aspectos do feitio moral da vilania e de uma dinâmica social mais abrangente.

Convém, antes dos apontamentos finais, tratar brevemente de um aspecto de comicidade do drama castroalvino que Décio de Almeida Prado não deixou de apontar em suas duas contribuições analíticas à fortuna de Gonzaga $a^{35}$ e que diz respeito às passagens situadas no limiar entre o melodrama e a comédia. Com efeito, certas passagens excessivamente melodramáticas se encontram a um passo do ridículo, como os monólogos do Governador ou as declarações de amor de Gonzaga a Maria. No entanto, o crítico teatral identifica toques de comédia nas soluções dramáticas encontradas por Castro Alves no direcionamento da trama, uma vez que o gênero cômico permite amplas liberdades de enredo, ${ }^{36} \mathrm{a}$ exemplo do desfecho da complicação no quarto ato, em que Luís defende a honestidade de Maria diante da armação documental arquitetada pelo Visconde de Barbacena, saindo do esconderijo de onde acompanhou a trama pérfida do vilão:

GONZAGA - Meu Deus! nem sequer eu poderei morrer descansado!... Quem me arrancará esta dúvida que mata?!

LUÍS (levanta o reposteiro da direita e sai) - Eu! (Todos conservaram-se pasmos. Ele arranca o bilhete da mão de Gonzaga e dirige-se à mesa onde o ajunta ao papel de que fora rasgado.) Este papel foi rasgado daqui há poucos instantes. ${ }^{37}$

Além dessa variedade, encontram-se "ares de comédia" na constituição do jogo de gato e rato entre Maria e o Governador no segundo ato, no qual a mocinha astuciosa engana seu adversário, entregando-lhe documentos falsos e queimando os verdadeiros:

O GOVERNADOR (precipita-se para a mesa da direita, de onde tira as cartas) - Ah! ah! ah! A senhora queria iludir-me... Louca. (Ajunta-as rapidamente sobre a mesa.) Agora é um duelo de morte... Oh! Eu sairei com as mãos cheias de sangue...

\footnotetext{
${ }^{35}$ Refiro-me aos capítulos sobre o drama histórico nacional em $O$ drama romântico brasileiro e na História concisa do teatro brasileiro.

${ }^{36}$ PRADO. O drama romântico, p. 182.

${ }^{37}$ ALVES. Obra completa, p. 656.
} 
MARIA (que tem queimado na vela os papéis verdadeiros, da Revolução) - E eu de cinzas...

O GOVERNADOR - E tu verás que o anjo... (voltando-se) Oh! maldição!

MARIA - Ah! ah! ah! Que o anjo queimou as asas do demônio... ${ }^{38}$

De fato, o que garante a comicidade da cena é a execução habilidosa de Maria da tromperie farsesca, por meio da qual consegue "pregar uma peça" no Visconde, relegando-o ao ridículo da inversão de papéis. Sendo o motor do riso, a burla é parte fundamental do mecanismo cômico da farsa, que alterna "ruse et tromperie", ${ }^{39}$ esperteza e engano. Dessa "comédia engenhosa", ${ }^{40}$ emprestada dos procedimentos farsescos tão populares à época de produção de Gonzaga, participam elementos compartilhados com melodrama, como as rivalidades, mascaradas, disfarces, esconderijos, fugas e emboscadas, que garantem a continuidade da tensão dramática ao longo da peça.

Dito isso, o exercício interpretativo das passagens cômicas selecionadas nos indica que convivem no drama de Castro Alves modalidades cômicas pertencentes ao alto cômico, como o chiste e os ditos espirituosos, e ao baixo cômico, a exemplo dos insultos, da inversão e da tromperie; esses últimos concentrados no personagem mais rebaixado, Silvério dos Reis. Não por acaso, os efeitos cômicos de Gonzaga ficam por conta de dois personagens secundários, pois afora Cláudio, a quem foi atribuída uma atuação periférica e bufona, e Silvério, cuja degeneração permite a atribuição de elementos farsescos à comicidade de seu papel, os demais personagens gozam de estatura moral elevada e certa homogeneidade de caráter $^{41}$ que os aproxima, antes dos

\footnotetext{
${ }^{38}$ ALVES. Obra completa, p. 617.

${ }^{39}$ REY-FLAUD. La Farce ou la machine à rire: théorie d'un genre dramatique (14501550), p. 4.

${ }^{40}$ PRADO. O drama romântico, p. 184.

${ }^{41}$ Ao contrário do que preconiza Victor Hugo, Castro Alves não aprofundou em complexidade os traços de caráter dos personagens principais de Gonzaga, mas fez com que cada personagem exibisse feições distintivas. Assim, o Visconde de Barbacena exibe a ganância e a obsessão; Silvério, a maldade e a esperteza; Cláudio, a comicidade e a galantaria; Gonzaga, o ideal e a nobreza de caráter; Maria Doroteia, a pureza de sentimento e a devoção ao amado, aproximando-os dos tipos.
} 
tipos melodramáticos do que dos tipos cômicos - ainda que, por vezes, essa linha de separação se mostre tênue na obra.

Filiando-se à tradição do drama romântico herdada de Victor Hugo, concluo que nessa produção acomodam-se, lado a lado, as tradições melodramática, cômica e trágica na urdidura do texto dramático. Talvez fosse por essa razão que Castro Alves afirmara que sua obra precisaria de uma "plateia ilustrada", ${ }^{42}$ para reconhecer os esforços literários empregados, embora fora de seu prazo estético. Dessa forma, conforme procurei demonstrar em minha análise, em meio ao "inesgotável impulso de justiça e humanidade" ${ }^{43}$ legado ao drama romântico pelo melodrama clássico e os arroubos sentimentais frequentes aos palcos oitocentistas, reside em Gonzaga ou a Revolução de Minas a pulsão cômica necessária à alternância entre gêneros em uma composição deliberadamente híbrida.

\section{Referências}

ALVES, Castro. Obra completa. Rio de Janeiro: Nova Aguilar, 1997.

ARAÚJO, Giovanna Gobbi Alves. A pintura das águas: um estudo da visualidade poética em A cachoeira de Paulo Afonso de Castro Alves. 2015. 195 f. Dissertação (Mestrado em Literatura Brasileira) - Faculdade de Filosofia, Letras e Ciências Humanas, Universidade de São Paulo, São Paulo, 2015.

BERGSON, Henri. O riso. Lisboa: Guimarães Editores, 1993.

FARIA, João Roberto. Ideias teatrais: o século XIX no Brasil. São Paulo: Perspectiva; FAPESP, 2001.

FARIA, João Roberto. Victor Hugo e o teatro romântico no Brasil. Lettres Françaises, Araraquara, v. 5, p. 105-116, 2003.

FREY, John Andrew. A Victor Hugo Encyclopedia. Westport: Greenwood Press, 1999.

\footnotetext{
${ }^{42}$ Cf. correspondência ao ator Joaquim Augusto Ribeiro de Souza de 25 de setembro de 1868 in ALVES. Obra completa, p. 756.

43 THOMASSEAU. O melodrama, p. 34. A expressão é citada por Thomasseau de um texto anônimo extraído do periódico francês Journal des débats de 1823.
} 
GRANDVILLE, J. J. Les fleurs animées. Introdução de Alphonse Karr. Texto de Alphonse Karr, Taxile Delord e Le Comte Foelix. Paris: Garnier Frères, 1867.

HUGO, Victor. Do grotesco e do sublime: tradução do Prefácio de Cromwell. Tradução, introdução e notas de Célia Berrettini. São Paulo: Perspectiva, 2004.

PRADO, Décio de Almeida. A personagem no teatro. In: CANDIDO, Antonio et al. A personagem de ficção. São Paulo: Perspectiva, 1968. p. 81-102.

PRADO, Décio de Almeida. História concisa do teatro brasileiro. São Paulo: Edusp, 2008.

PRADO, Décio de Almeida. O drama romântico brasileiro. São Paulo: Perspectiva, 1996.

PROPP, Vladímir. Comicidade e riso. Tradução de Aurora Fornoni Bernadini e Homero Freitas de Andrade. São Paulo: Ática, 1992.

REY-FLAUD, Bernadette. La Farce ou la machine à rire: théorie d'un genre dramatique (1450-1550). Genèvre: Librairie Droz, 1984.

THOMASSEAU, Jean-Marie. O melodrama. Tradução e notas de Claudia Braga e Jacqueline Penjon. São Paulo: Perspectiva, 2012.

Recebido em: 20 de dezembro de 2017. Aprovado em: 22 de fevereiro de 2018. 